\title{
Haemophilia A in a Female Patient with Turner Syndrome
}

\begin{abstract}
Afrose $\mathrm{S}^{1}$
Abstract

A 28-year-old female presented with occasional swelling of knees and prolonged bleeding after trauma. She also complained of gum bleeding in few occasions. She also gave history of primary amenorrhoea and failure of development of secondary sexual character. There was negative family history of bleeding tendency in both maternal and paternal family. Her investigation profile showed prolonged Partial Thromboplastin Time and reduced factor VIII activity (2.5\%). Karyotyping showed (45 XO) Turner syndrome. This is the reported first case of association of Turner syndrome with moderate Haemophilia A in Bangladesh.
\end{abstract}

Key words: Haemophilia, Turner syndrome, female haemophilia.

\section{Introduction}

Haemophilia A is a sex-linked recessive disorder that is expressed in males who inherit the haemophilic gene from their mothers and because of which produces reduced amount of factor VIII. Haemophilia A is the most common coagulation factor deficiency around the world. ${ }^{1}$ It affects all ethnic population and its prevalence varies among different countries but estimated at a rate of 3-20 cases per 1,00,000 population. ${ }^{2,3}$ Being an $\mathrm{X}$-linked recessive disorder, females are generally not affected, although they can be carriers of this disorder. A classical female haemophilia is possible only when a carrier female marries a haemophilic male, of which there are only few reports in the literature. ${ }^{4-6}$ In India, as consanguineous marriages are very common in certain communities (up to $30 \%$ ), the likelihood of encountering female haemophilia is higher, although one case is found out of 1600 haemophilia families. ${ }^{7}$ In certain conditions, it can affect females too: $\mathrm{X}$-chromosome lionization, inactivation of normal $\mathrm{X}$ chromosome in a carrier and Turner's syndrome. $1,8,9$ Haemophilia is classified clinically on presence of clotting factor activity into - severe when $<1 \%$ of normal, moderate when $1-5 \%$ of normal and mild $5-40 \%$ of normal.

Turner syndrome was first reported as a clinical syndrome prior to availability of karyotyping in 1938 by Henri Turner, an Oklahoma physician. ${ }^{10}$ It is the most common sex abnormalities in female occurs in approximately 1 in 2000 to 1 in 2500 live female birth based on epidemiological and newborn genetic screening data from Europe, Japan and the United States. ${ }^{11}$ Turner syndrome occurs with more or less the same prevalence in all ethnic groups and in different

\footnotetext{
Author

1. *Salma Afrose, Professor of Haematology \& Honorary Senior Consultant, Department of Transfusion Medicine \& Clinical Haematology, BIRDEM General Hospital, Shahbag, Dhaka 1000. Phone: +8801552428020, email: salma_afrose@yahoo.com

* for correspondence

26 | Page
}

countries. Its number is declining in some countries due to termination of pregnancy. On the other hand, most gestations (likely more than 99\%) affected by $\mathrm{X}$ chromosome monosomy $(45, \mathrm{XO})$ do not survive to birth and $45 \mathrm{XO}$ genotype is found in at least 10 percent of spontaneous abortion. ${ }^{12,13}$

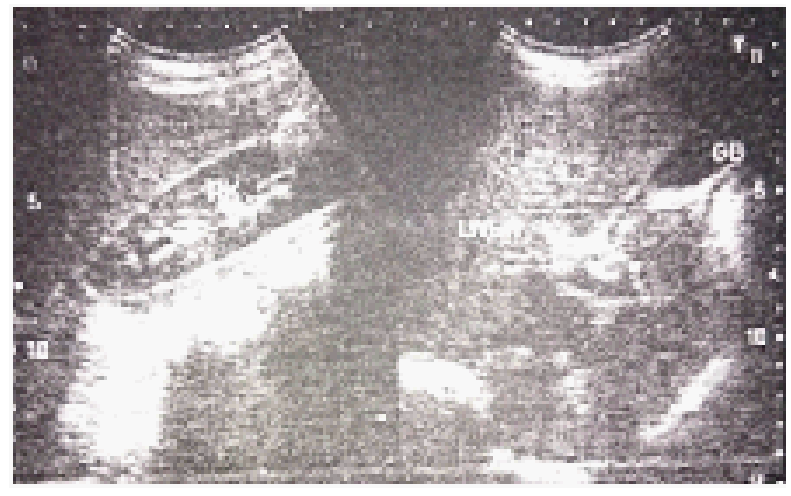

Figure 1: USG of abdomen and pelvis showing absence of uterus and ovaries

\section{Case Report}

A 28-year-old female presented with occasional swelling of knees and prolonged bleeding after trauma. She also complained of gum bleeding in few occasion. She needed transfusion 6-10 times for severe bleeding due to trauma. She also gave history of primary amenorrhoea and failure of development of secondary sexual character. There was negative family history of bleeding tendency in both maternal and paternal sides. On examination she was found to be of short stature. Her facial appearance included low nasal bridge, short nose, smooth philtrum and thin upper lip. She also had webbing of neck. Secondary sexual character was absent. The investigation results were as follows. Bleeding time: 3 minutes; prothrombin time (PT):13 seconds (control 12 seconds); activated partial

Haematol J Bangladesh 2017; 1(1): 26-27 


\section{Case Report}

thromboplastin time (APTT): 116.1 seconds (control 28 seconds); APTT mixing study: 38.3 seconds (immediate) \& 40.6 seconds ( 2 hours after incubation); factor VIII: $2.6 \%$ (normal: $60-150 \%$ ); Von Willebrand Ag (vWF:Ag): 88\% (normal: 50-160\%); haemoglobin: $10 \mathrm{gm} / \mathrm{dl}$; Total WBC: $9.08 \times 10^{9} / \mathrm{L}$; Platelet: 255 $\mathrm{x} 10^{9} / \mathrm{L}$ ). Ultrasonography report shows absence of uterus and ovaries. Chromosomal analysis (Karyotype) shows abnormal female chromosome monosomy X, $45 \mathrm{XO}$, consistent with Turner syndrome.

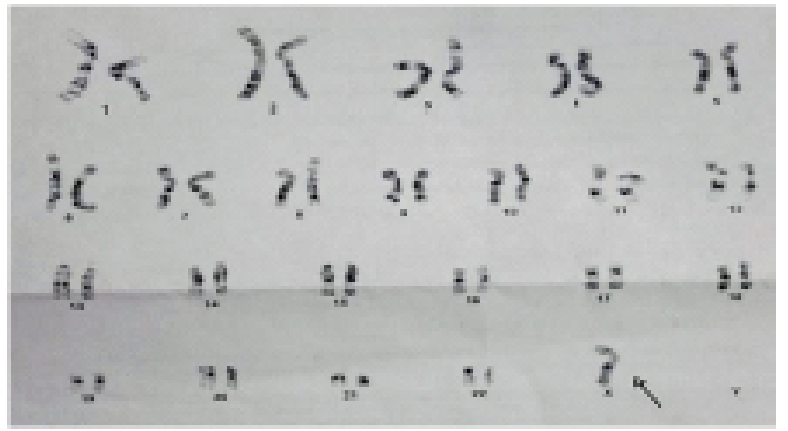

Figure 2: Karyotype showing 45X0 (Turner Syndrome)

\section{Discussion}

The expression of a recessive $\mathrm{X}$-linked disorder such as haemophilia A and B is rare in females. The incidence of haemophilia is about 1:7500 live male birth and 1:25,000,000 live female birth. ${ }^{14}$ Although Turner syndrome incidence is 1:2000 to 1:2500, very few number of haemophilia with concomitant Turner syndrome have been reported. ${ }^{9}, 12,15-22$ This is the first reported case of Turner syndrome with haemophilia in Bangladesh. Our patient, as she has moderate haemophiliaand had primary amenorrhoea, her symptoms were mainly when becomes injured, therefore, she presented lately. She lives in a remote place and had no facilities for diagnosis.

\section{References}

1. Mansouritorghabeh, H. (2015). Clinical and Laboratory Approaches to Haemophilia A. Iranian journal of medical sciences 2015; 40:194-205.

2. DiMichele D, Chuansumrit A, London AJ, Thompson AR, Cooper CG, Killian RM, Ross LF, Lillicrap D, Kimmelman J. Ethical issues in Haemophilia. Haemophilia 2006; 12:30-35. doi: 10.1111/j.13652516.2006.01258.x. PubMed: PMID: 16683994.

3. Stonebraker JS, Bolton-Maggs PH, Soucie JM, Walker I, Brooker M. A study of variations in the reported HA prevalence around the world. Haemophilia. 2010; 16:20-32. PubMed PMID: 19845775.

4. Pavlova A, Brondke H, Müsebeck J, Pollmann H, Srivastava A, Oldenburg J. Molecular mechanisms underlying haemophilia A phenotype in seven females. J Thromb Haemost 2009; 7:976-982. [PubMed]

5. Martín-Salces M, Venceslá A, Alvárez-Román MT, Rivas I, Fernandez I, Butta N, Baena M, Fuentes-Prior P, Tizzano EF, Jiménez-Yuste V. Clinical and genetic findings in five female patients with haemophilia A: Identification of a novel missense mutation, p.Phe2127Ser.
Thromb Haemost 2010;104:718-723. [PubMed]

6. Shetty S, Ghosh K, Mohanty D. Haemophilia B in a female. Acta Haematol 2001; 106:115-117. [PubMed]

7. Nair PS, Shetty S, Ghosh K. A homozygous female haemophilia A.Indian Journal of Human Genetics 2012;18(1):134-136.

8. Nisen PD, Weber PG. Nonrandom X chromosome DNA methylation patterns in haemophilia c females. J Cli Invest 1989; 83:140-143. doi: 10.1172/JCI114028. PubMed PMID: 2564852; PubMed Central PMCID: PMC303834.

9. Williams VK, Suppiah R, Coppin B, Nicholls CM, Simsek A, McGregor LK. Investigation of inflicted injury in a young girl reveals mild haemophilia $\mathrm{A}$ and Turner's syndrome. Int $\mathrm{J}$ Lab Haematol 2012; 34:98-101. doi: 10 .1111/j .1751- 553 X .2011. 013 47.x. Pub Med PMID: 21707934.

10. Turner HH. A syndrome of infantilism, congenital webbed neck, and cubitus valgus. Endocrinology 1938; 28:566.

11. Backeljauw P (2017). Clinical manifestations and diagnosis of Turner syndrome. [online] Available at: https://www.uptodate.com/ contents/clinical-manifestations-and-diagnosis-of-turnersyndrome\#H2 [Accessed 18 Oct. 2017].

12. Baena N, De Vigan C, Cariati E, Clementi M, Stoll C, Caballín MR, Guitart M. Turner syndrome: Evaluation of prenatal diagnosis in 19 European registries. American Journal of Medical Genetics Part A. 2004;129A (1):16-20. DOI: 10.1002/ajmg.a.30092.

13. Iyer NP, Tucker DF, Roberts SH, Jacobs P. Outcome of fetuses with Turner syndrome: A 10-year congenital anomaly register based study. J Matern Fetal Neonatal Med. 2012; 25(1): 68-73. doi: 10.3109/14767058. 2011.564688.

14. Haemophilia (n.d.) Available at: https://www.thbdf.org/index. php/about-blood-disorders/hemophilia [Accessed 18 Oct. 2017].

15. Gilchrist GS, Hammond D, Melnyk J. Haemophilia A in a phenotypically normal female with XX/XO mosaicism. The New England Journal of Medicine 1965; 273: 1402-1406. doi: 10.1056/NEJM196512232732602.

16. Harakati MS. Female haemophilia A in a Saudi family: family study and review of the literature. Ann Saudi Med 1991;11(2):218-220.

17. Shahriari M, Bazrafshan A, Moghadam M, Karimi M. Severe haemophilia in a girl infant with mosaic Turner syndrome and persistent hyperplastic primary vitreous. Blood Coagul Fibrinolysis 2016;27(3):352-353. doi: 10.1097/MBC.0000000000000424.

18. Panarello C, Acquila M, Caprino D, Gimelli G, Pecorara M, Mori PG. Concomitant Turner syndrome and haemophilia A in a female with an $\operatorname{idic}(\mathrm{X})(\mathrm{p} 11)$ heterozygous at locus DXS52. Cytogenet Cell Genet 1992;59(4):241-242.

19. Weinspach S, Siepermann M, Schaper J, Sarikaya-Seiwert S, Rieder H, Gerigk M, Höhn T, Laws HJ. Intracranial haemorrhage in a female leading to the diagnosis of severe haemophilia $\mathrm{A}$ and Turner syndrome. Klin Padiatr 2009;221(3):167-171. doi: 10.1055/s-0029-1220701.

20. Suega K. A woman with sporadic haemophilia -B die because of cerebral bleeding: a rare case in Bali-Indonesia. Bali Med J 2015; 4(2):61-67.

21. Seeler RA, Vnencak-Jones CL, Bassett LM, Gilbert JB, Michaelis RC. Severe haemophilia A in a female: a compound heterozygote with nonrandom X-inactivation. Haemophilia 1999;5(6):445-449.

22. Mühle C, Zenker M, Chuzhanova N, Schneider H. Recurrent inversion with concomitant deletion and insertion events in the coagulation factor VIII gene suggests a new mechanism for Xchromosomal rearrangements causing haemophilia A. Hum Mutat 2007;28(10):1045. 